\title{
Phylogenetic of Four Bamboo Genera Based on NdhH Sequences, Chloroplast DNA
}

\author{
Annisa $^{1 *}$, Rini Hafzari ${ }^{1}$, Budi Irawan $^{1}$, Tia Setiawati ${ }^{1}$, Joko Kusmoro $^{1}$ \\ ${ }^{1}$ Department Biology, Faculty of Mathematics and Natural Sciences Natural Science, Universitas Padjadjaran, Indonesia
}

\begin{abstract}
Bamboos are versatile plants with many usages. Indonesia has a high diversity of Bamboos species and has been using them for a long time. As multipurpose plants, they are vulnerable to over exploration. Much of the bamboo land has been converted into housing or agricultural land. Development and conservation need to be balanced, to protect the genetic diversity, bamboo in particular. We studied the relationship among four genera of bamboo that mostly found in Indonesia using gene that presents in chloroplast DNA, $n d h H$. DNA from twenty-four samples from Bambusa, Dendrocalamus, Gigantochloa and Schizostachyum were extracted and amplified using specific $n d h H$ primer. Sequencing results were analysed with BioEdit 7.2 software. Phylogenetic tree was build using raxmlGUI 2.0 software. The result showed that $n d h H$ gene generated good sequence quality. It has small variation among samples. The result suggested that $n d h H$ was able to differentiate some species within Schizostachyum, however; it was not a success for others.
\end{abstract}

\section{Introduction}

Chloroplast genome, also refereed as plastome, is formed by the selection of basic cellular functions which are expected to be a recorded trace of the adaptation process of various types of plants during their evolutionary process [1]. This genome is recognizable of being highly conserved and have a smaller effective population size $[2,3]$. Mutations region at plastome loci is potentially useful for molecular species identification $[4,5]$. It is also known to be materially inherited, and it is more conserved than the nucleus and mitochondrial DNA $[6,7]$. The advantages of the plastome, then, utilized in many aspects, ranging from genetic diversity study, development of plant breeding programs, and standardization of raw materials. Also, chloroplast genome is very useful for studying phylogenetic relationship among taxa.

DNA barcoding for plant is mostly design from chloroplast genes. This barcode intended for quick and reliable species-level identifications across all forms of life, including animals, plants, fungi, and microorganisms. This system uses short gene regions and standardized. [8-10]. DNA barcode also reliable for studying phylogenetic relationship among living things. The Consortium for the Barcode for Life (CBOL) recommends $M a t K$ and $\mathrm{Rbcl}$ as barcode for plants [11]. However, these recommended loci might not work for all plants [12]. Study using MatK was not succeed in separating Bambusa species [13]. Development of new primers from different of plastome loci and test their ability to differentiate plants has become essential. $\mathrm{NdhH}$ (NADH dehydrogenase-like $\mathrm{H}$ ) is one locus that potential as barcode other than the universal DNA barcode for complicated species and cryptic species [14].This a good candidate especially for complicated species such as bamboo.
Bamboos (Bambusoideae) has long been used in everyday life by the Indonesian people. Since long time ago, Indonesian society has considered bamboo as a versatile plant. Bamboo is consumed as a vegetable, material for household tools, musical instruments, building materials, medicine, pulp and paper, cosmetics and source for bioenergy [15-18].

Bamboo also has a very important roles for the environment. It supports lower light intensity and protects against ultraviolet rays. For area that prone to landslide, this plant can be used to control soil erosion [19]. Java Island is estimated to have 60 types of bamboo. Bogor Botanical Garden has a bamboo collection consisting of 11 genera and 43 species [20]. Based on these data, it can be ascertained that bamboo is a very abundant resource and has quite high diversity. However, because bamboo is considered very easy to grow and it can actually regrow after harvesting, its current use and consumption of bamboo resources has created some problems that will affect sustainable development of bamboo resources. Not to mention many lands uses changes have resulted in limited availability of bamboo. The knowledge of genetic background in bamboo plays crucial roles in maintaining its sustainability. Our study aimed to develop new chloroplast DNA marker from $\mathrm{NdhH}$ and study its strength in differentiating different bamboo samples from 4 different genera: Bambusa, Dendrocalamus, Gigantochloa and Schizostachyum with phylogenetic tree.

\section{Material and Methods}

\footnotetext{
* Corresponding author : annisa18040@mail.unpad.ac.id
} 


\subsection{Sample Collection}

The samples used in this study were collected from Cibeurih Hamlet, Nagarawangi Village Sumedang; Gajeboh Hamlet, Kanekes Baduy Village; Talaga Hamlet, Kutamanah Village, Purwakarta; and from the Bogor Botanical Gardens (BBG). Sampling was carried out using the Tuner (2015) method which was modified by taking part of young leaves, cleaned using $70 \%$ alcohol and put into plastic samples that had been filled with silica gel. Comparison of sample weight and weight of silica gel was 1:10. Then the sample plastic was labeled and put in the sample storage box. The following is a list of samples used in this study (Table 1). Sample no. 20-24 were taken from the field and carefully characterized using their vegetative characters based on [21].

Table 1. Lists of Samples and location

\begin{tabular}{|c|c|c|}
\hline No. & Species & Location \\
\hline 1 & $\begin{array}{l}\text { Bambusa balcoa } \\
\text { Roxb }\end{array}$ & \\
\hline 2 & $\begin{array}{l}\text { B. polymorpha } \\
\text { Munro }\end{array}$ & \\
\hline 3 & $\begin{array}{l}\text { B. vulgaris } \\
\text { var.vulgaris }\end{array}$ & \\
\hline 4 & $\begin{array}{l}\text { B. vulgaris var. } \\
\text { striata }\end{array}$ & \\
\hline 5 & B. glaucophylla & \\
\hline 6 & $\begin{array}{l}\text { Dendrocalamus } \\
\text { brandisii (Munro) } \\
\text { Kurz }\end{array}$ & \\
\hline 7 & $\begin{array}{l}\text { D. giganteus } \\
\text { Wallich ex Munro }\end{array}$ & \\
\hline 8 & $\begin{array}{l}\text { D. latiforus Laut. \& } \\
\text { K. Schum }\end{array}$ & \\
\hline 9 & $\begin{array}{l}\text { D. asper (Schultes } \\
\text { f.) Backer ex Heyne }\end{array}$ & Bogor Botanical \\
\hline 10 & $\begin{array}{l}\text { Gigantochloa atter } \\
\text { (Hassk.) Kurz }\end{array}$ & \\
\hline 11 & $\begin{array}{l}\text { G. atroviolacea } \\
\text { Widjaja }\end{array}$ & \\
\hline 12 & G. kuring Widjaja & \\
\hline 13 & $\begin{array}{l}\text { G. verticillata } \\
\text { (Willd.) Munro }\end{array}$ & \\
\hline 14 & G. robusta Kurz & \\
\hline 15 & $\begin{array}{l}\text { Schizostachyum } \\
\text { blumei Nees }\end{array}$ & \\
\hline 16 & $\begin{array}{l}\text { S. brachycladum } \\
\text { Kurz }\end{array}$ & \\
\hline 17 & $\begin{array}{l}\text { S. caudatum Backer } \\
\text { ex Heyne }\end{array}$ & \\
\hline 18 & $\begin{array}{l}\text { S. longispiculatum } \\
\text { (Kurz ex Munro) } \\
\text { Kurz }\end{array}$ & \\
\hline 19 & S. zolingeri Steudel & \\
\hline 20 & B. maculata & $\begin{array}{c}\text { Talaga Hamlet, } \\
\text { Kutamanah }\end{array}$ \\
\hline
\end{tabular}

\begin{tabular}{|c|c|c|}
\hline & & $\begin{array}{c}\text { Village, } \\
\text { Purwakarta }\end{array}$ \\
\hline 21 & S. silicatum & $\begin{array}{c}\text { Kadu Ketug } \\
\text { Hamlet, Kanekes } \\
\text { Village, Baduy, } \\
\text { Banten }\end{array}$ \\
\hline 22 & $\begin{array}{l}\text { G. } \\
\text { pseudoarundinacea } \\
\text { (Steudel ) }\end{array}$ & $\begin{array}{c}\text { Gajeboh Hamlet, } \\
\text { Kanekes Village } \\
\text { Baduy, Banten } \\
\end{array}$ \\
\hline 23 & S. iraten Steudel & Cibeurih Hamlet, \\
\hline 24 & $\begin{array}{l}\text { G. apus (J.A. \& J.H } \\
\text { Schultes) Kurz }\end{array}$ & $\begin{array}{c}\text { Nagarawangi } \\
\text { Village, Sumedang }\end{array}$ \\
\hline
\end{tabular}

\subsection{DNA Chloroplast Primary Design}

The new ndHh primer was designed based on the results of the complete alignment of the ndhH gene sequence. The primer design was following Schäffer et al. (2017). All sequence data were downloaded from the National Center for Biotechnology Information (NCBI) GenBank (Table 2). Sequence alignment was done by using the ClustalW software contained in the MEGA X software (Kumar et al., 2018). The highly conserved areas flanking the polymorphism area were located with the aim of getting an amplification product of around 300$350 \mathrm{bp}$.

Table 2. Accession number and species name used to design $n d H h$ primer

\begin{tabular}{ccc}
\hline No & $\begin{array}{c}\text { Accession } \\
\text { number }\end{array}$ & Species name \\
\hline 1 & NC_036700.1 & Rhipidocladum pittieri \\
2 & MH410122.1 & Chusquea culeou \\
3 & KJ870990.1 & C. spectabilis \\
4 & KP319242.1 & Chusquea sp. \\
5 & KJ871001.1 & C. liebmannii \\
6 & NC_027490.1 & C. circinata \\
7 & KP793062.1 & Guadua weberbaueri \\
8 & NC_0297491 & G. angustifolia \\
9 & KT373814.1 & G. chacoensis \\
10 & KJ870997.1 & Olmeca reflexa \\
11 & KJ871003.1 & Otatea acuminata \\
12 & NC_028631.1 & O. glauca \\
13 & NC_024668.1 & Bambusa multiplex \\
14 & KJ870989.1 & B. arnhemica \\
15 & KJ870988.1 & B. bambos \\
16 & MH410121.1 & B. ventricosa \\
17 & HQ337797.1 & B. emeiensis \\
18 & FJ970916.1 & Dendrocalamus latiflorus \\
19 & NC_026961.1 & Greslania sp. \\
& &
\end{tabular}




\section{$20 \quad$ KJ870994.1 Hickeliamadagascariensis \\ $21 \quad$ KJ870995.1 Neohouzeaua sp.}

Sequences that have been obtained were then inputted into Primer3 software [22]. For the primary pick process. Potential primers were then evaluated and optimized using the BLAST program in NCBI and NetPrimer

software (http://www.premierbiosoft.com/netprimer) to detect secondary structures, hairpins, self-dimers and crossdimers in primer pairs, as well as in-silico PCR.

\subsection{DNA Isolation}

DNA extraction was carried out using the Doyle and Doyle method modified by Vijay and Uttamkumar [23]. DNA quantification was done with plate spektrofotometer (multimode reader tecan m200 pro).

\subsection{PCR Amplification and Sequencing}

PCR reaction was following [24]. The total reaction was $25 \mu \mathrm{L}$ consisting of DNA template ( $20 \mathrm{ng}$ ), forward and reverse primers $(10 \mu \mathrm{M}), \mathrm{MgCl} 2(25 \mathrm{mM}), 1 \mathrm{X}$ PCR buffer (Promega), Nuclease Free Water to a volume of $25 \mu \mathrm{L}$. PCR amplification was performed using Thermal Cycler Chain Reaction (Biorad T100) with a total reaction of 35 cycles consisting of pre-denaturation of $94{ }^{\circ} \mathrm{C}$ for 3 minutes, denaturation of $94{ }^{\circ} \mathrm{C}$ for 30 seconds, annealing $61{ }^{\circ} \mathrm{C}$ for 30 seconds, elongation 72 ${ }^{\circ} \mathrm{C}$ for 30 seconds, final elongation $72{ }^{\circ} \mathrm{C}$ for 5 minutes. Visualization of PCR results was carried out using electrophoresis. Electrophoresis was carried out using $1.5 \%$ agarose gel in a $1 \mathrm{X}$ TAE buffer at 70 volts for 60 minutes. After completion, the gel was stained with Red Gel and visualized under the UV transilluminator to see the amplified DNA band. Sequencing was done by 1st BASE.

\subsection{Phylogenetic Analysis}

The DNA sequencing result was analysis first using software BioEdit dan chromaspro. The DNA sequences were then aligned using the ClustalW program on MEGA X software with default setting to find the consensus sequences among species. These sequences then used to construct the phylogenetic tree [25]. Phylogenetic tree was done using software RAxML (Randomized Axelerated Maximum Likelihood) with software RAxMLGUI 2.0[26]. Parameter Analysis: $\mathrm{ML}+$ rapid bootstrap with 1000 replications.

\section{Result and Discussion}

\subsection{Sequence analysis}

The sequencing result showed all 24 samples were successfully amplified with the new designed primer. The alignment indicated that out of four genera, Schizostachyum species were the ones that have variations on their ndhH sequences compared to others (Bambusa, Giganthocloa, and Dendrocalamus) (Figure. $1)$.

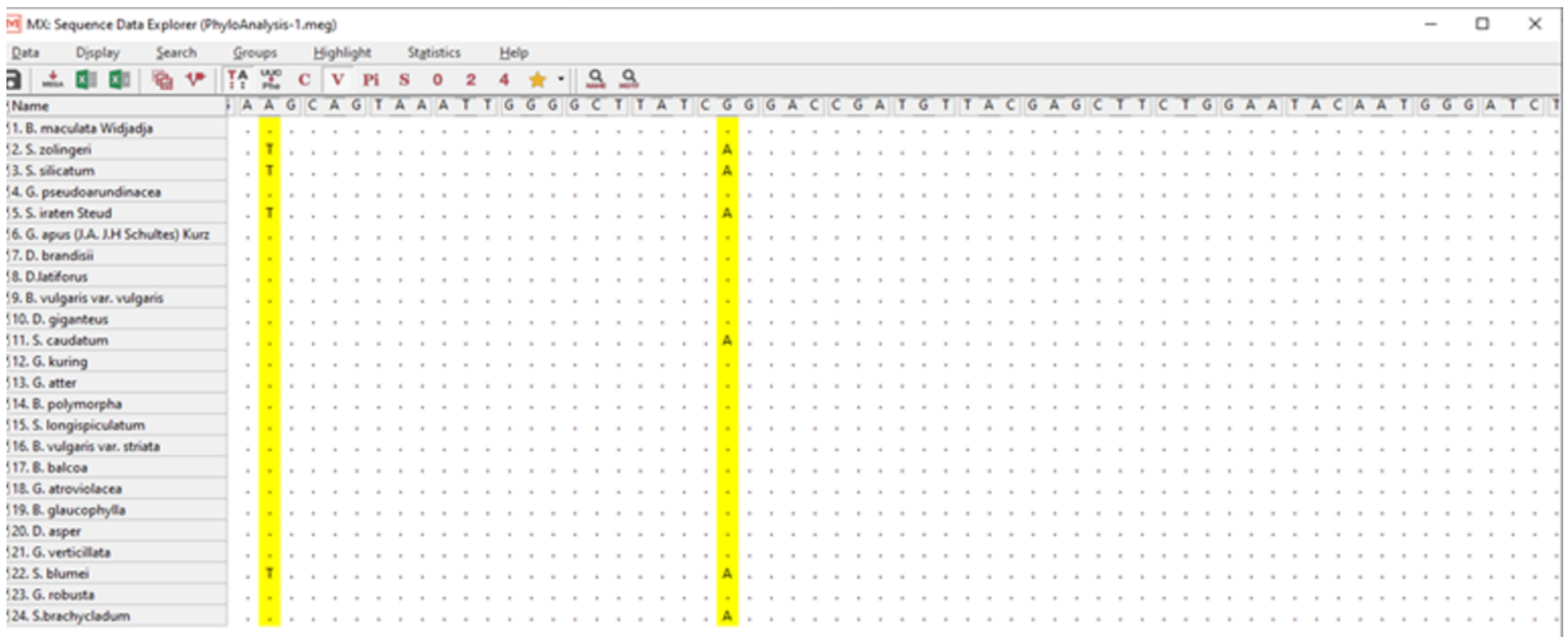

Figure 1. DNA variation among 24 samples. Note: “.” means the base are the same in all 24 samples. Yellow color indicates the changes base in the sample

The PCR primer were designed to amplify the most varied area of $n d h H$ from the GenBank bamboos data (table 2). The length of the PCR product was $240 \mathrm{bp}$.
Even though this is a small DNA PCR product, it was tested using with in-silico PCR. The bioinformatics approach to check the primer was confirmed with 
laboratory data. Schizostachyum showed changes in the base from Adenine $(A) \rightarrow$ Thymine $(T)$ and Guanine $(G)$ $\rightarrow$ Adenin (A) (as shown in figure 1), except for $S$. longispiculatum. It might be there are two types of mutations in the $n d h H$ sequence from samples we studied. First is silent mutation, where the change in the DNA sequence does not change the amino acid that form the protein [27]. Secondly, is missense mutation, where the substitution of single base pair changes the genetic code and produces different amino acid than usual [28]. The changes in DNA base of $n d h H$ may also drive the separation of Schizostachyum from other genera. Bambusa, Dendrocalamus and Gigantochloa belong to Bambusinae subtribe while Schizostachyum is belong to Melocanninae [29].

\subsection{Phylogenetic tree result}

The phylogenetic analysis showed that even though the samples were collected from different places, the grouped were not divided by the region but more to genus (figure 2). This is especially seen in most of Schizostachyum which form a monophyletic relationship. However, $S$. longispiculatum was separated from the grouped and closer to B. vulgaris var. striata and G. robusta.

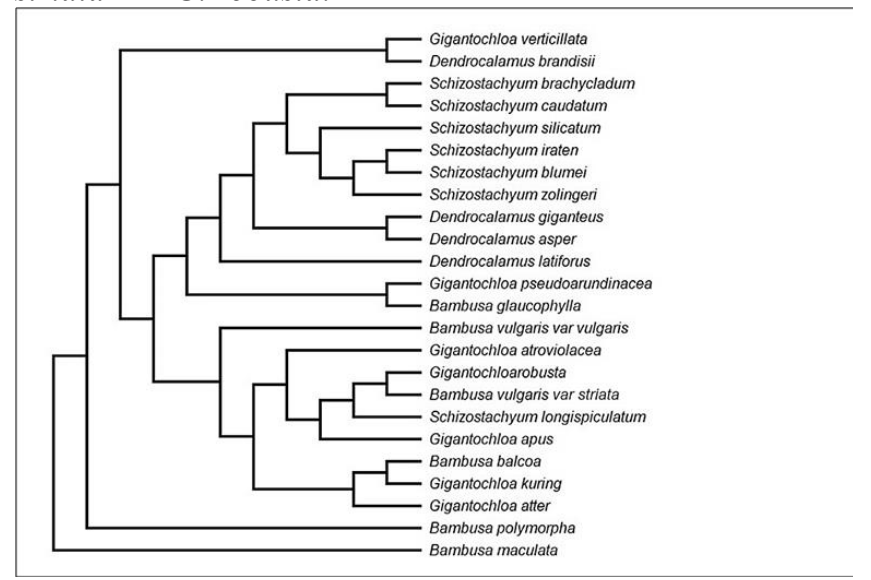

Figure 2. Phylogenetic of 24 samples bamboos based on $n d h H$ sequence

Though $\mathrm{NdhH}$ was also able separate $D$. giganteus from $D$. asper, it was not work very well with other samples from another genus. Our research used $G$. kuring which we believe is the first to be used compared to any other study for molecular identification in bamboo. Although this gene was not able to separate $G$. kuring from B. balcoa, our result is similar with the work done using morphological characters [30]. The research grouped $G$. kuring in same group as $B$. balcoa in cluster b.1 along with some Gigantichloa, Bambusa and Neololeba. Our result with $n d h H$ was different with previous work done with RAPD, where Schizostachyum species were not cluttered together [31].

Bamboos that are grouped into BDG are still difficult to be separated with this marker. Types of bamboo are usually characterized by their morphological characters because it is difficult to find their generative stages [29]. The development of markers, either from chloroplast DNA or nuclear DNA, is to assist the problem that might arise due to the limitation. The result of this research suggests that ndhH might have work better for Schizostachyum compared to other genera. This requires further research using species from different places and tested the loci to amplify fresh samples as well as aged samples such as herbariums.

\section{Conclusion}

$N d h H$ was able to differentiate some species within Schizostachyum, however; it was not a success for others.

\section{Acknowledgment}

Authors like to give sincere thanks to RISTEK-BRIN of the Republic of Indonesia who has funded this research (No. 1827/UN6.3.1/LT/2020). We also thank The Bogor Botanical Gardens who has provided us with samples.

\section{References}

1. Hu, S., Sablok, B. Wang, D. Qu, E. Barbaro, R. Viola, M. Li, and C. Varotto. BMC Genomics. 16, 1-14 (2015).

2. Jansen, R.K., Cai, L. A. Raubeson, H. Daniell, C. W. Depamphilis, J. Leebens-Mack, K. F. Müller, M. Guisinger-Bellian, R. C. Haberle, A. K. Hansen, T. W. Chumley, S. B. Lee, R. Peery, J. R. McNeal, J. V. Kuehl, and J. L. Boore. Proc Natl Acad Sci USA. 104,19369-74 (2007).

3. Li, P., S. Zhang, F. Li, S. Zhang, H. Zhang, X. Wang, R. Sun, G. Bonnema, and T. J. A. Borm. Front. Plant Sci. 8, 111 (2017).

4. Krawczyk, K., M. Nobis, K. Myszczyński, E. Klichowska, and J. Sawicki. Scientific Reports. 8, 1924 (2018).

5. Pischl, P.H., S. V. Burke, E. M. Bach, and M. R. Duvall. Ecol. Evol.. 10, $7602-7615$ (2020).

6. Thode, V.A. and L.G. Lohmann. Front. Plant Sci. 10, 796-796 (2019).

7. Achakkagari, S.R., M. Kyriakidou, H. H. Tai, N. L. Anglin, D. Ellis, and M. V. Strömvik. PLOS ONE. 15, e0240124 (2020).

8. Blaxter, M. Nature. 421,122-123 (2003).

9. Hebert, P.D.N., A. Cywinska, S. L. Ball, and J. R. deWaard. Proc. Royal Soc. B 270, 313-321 (2003).

10. Kress, W.J. and D.L. Erickson. Methods Mol Biol. 858, 3-8 (2012).

11. Hollingsworth, P.M., et al. Proceedings of the National Academy of Sciences. 106, 12794-12797 (2009). 
12. Singh, H.K., I. Parveen, S. Raghuvanshi, and S. B. Babbar. BMC Research Notes. 5, 42 (2012)

13. Das, M., P. Mahadani, R. Singh, K. Karmakar, and S. Ghosh. Journal of Environment and Sociobiology. 10, 49-54 (2013).

14. Ślipiko, M., K. Myszczyński, K. Buczkowska, A. Bączkiewicz, M. Szczecińska, and J. Sawick., BMC plant biology, 20, 243-243 (2020).

15. Akmal, I., N Arimbi, N. Primasanti, W. Sawitri, D. Kusumawardhani, and D. Soraya. Bambu untuk Rumah Modern. 2011, Jakarta: Gramedia Pustaka Utama.

16. Widjadja, E.A., The Spectacular Indonesia bamboos. 2019, Jakarta: Polagrade.

17. Sulaeman, Y., F. A. Syamani, W. Fatriasari, and Subyakto. IOP Conf. Series: Earth and Environmental Science, 141, 012039 (2018).

18. Nirmala, C., M. S. Bisht, H. K. Bajwa, and O. Santosh. Trends Food Sci. Technol. 77, 91-99 (2018).

19. Ramakrishnan, M., M. Zhou, K. Baskar, and S.M. Packiam. Austin J EnvironToxicol. 4: p. 1023 (2018).

20. Zulkarnaen, R.N. and P.S. Adila, Pros Sem Nas Masy Biodiv Indon. 1, 534-538 (2015).

21. Dransfield, S. and E.A. Widjadja, Plant Resources of South-East Asia No. 7 Bamboos, ed. S. Dransfield and E.A. Widjadja. 1995, Bogor: Prosea Foundation

22. Kõressaar, T., M. Lepamets, L. Kaplinski, K. Raime, R. Andreson, and M. Remm. Bioinformatics. 34, 1937-1938 (2018).

23. Waghmare, V. N. and S. B. Uttamkumar. Afr. J. Biotechnol. 12, 4446-4452 (2013).

24. Wattoo, J., Z. Saleem, M. S Shahzad, A. Arif, A. Hameed, and A. Saleem. Adv. life sci.. 4 (2016).

25. Sternke, M., K.W. Tripp, and D. Barrick. PNAS 116,11275-11284 (2019).

26. Silvestro, D. and I. Michalak. Organisms Diversity \& Evolution. 12, 335-337 (2012).

27. Patel, U.R., S. Gautam, and D. Chatterji. ACS omega, 4,17714-17725 (2019).

28. Zhang, Z., M. A. Miteva, L. Wang, and E. Alexov. Comput Math Methods Med. 2012: p, 805827 (2012).

29. Das, M., S. Bhattacharya, P.K. Singh, T. S. Filgueiras, and A. Pal. Bamboo Taxonomy and Diversity in the Era of Molecular Markers, in Advances in Botanical Research. 2008, Academic Press. p. 225-268.

30. Fitriana, R.A T. Yulistyarini, A. Soegianto, and N.R. Arduarin. Jurnal Produksi Tanaman. 5, 812820 (2017).

31. Annisa, R. Hafzari, T. Setiawati, B. Irawan, and J. Kusmoro. Folia For Pol Ser A For. 61, 255-266 (2019)M. Ben Rabha, M.F. Boujmil, M. Saadoun, B. Bessaïs, Eur. Phys. J. Appl. Phys. (to be published) 